\title{
Indications for sexology consultation in women after surgical treatment due to breast cancer
}

\author{
Joanna Streb ${ }^{1, A-F}$, Marcin Jacek Jabłoński ${ }^{2, A-D, F}$, Agnieszka Słowik ${ }^{1, B, D}$, Dorota Babczyk ${ }^{3, C}$, \\ Robert Jach ${ }^{3, E-F}$ \\ 1 Department of Oncology, The Jagiellonian University Medical College Kraków, Poland \\ ${ }^{2}$ Institute of Psychology, Faculty of Philosophy, University of Philosophy and Education Ignatianum in Krakow, Poland \\ ${ }^{3}$ Department of Gynaecologic Oncology, The Jagiellonian University Medical College Kraków, Poland \\ A - Research concept and design, B - Collection and/or assembly of data, C - Data analysis and interpretation, \\ $D$ - Writing the article, $E$ - Critical revision of the article, $F$ - Final approval of article
}

Streb J, Jabłoński MJ, Słowik A, Babczyk D, Jach R. Indications for sexology consultation in women after surgical treatment due to breast cancer. Ann Agric Environ Med. 2019; 26(2): 379-384. doi: 10.26444/aaem/89733

\begin{abstract}
Introduction and objectives. Surgical treatment due to brest cancer have an impact on women sexuality. There is a need for research about effective indications for sexology consultation in women after such treatment. The aim of this study is to determine the indications for sexology consultation in women after surgical treatment for breast cancer.

Materials and method. We tested 42 women patients diagnosed with breast cancer who had undergone mastectomy 3 months before the study. 3 months after the surgery the women were surveyed using the Polish version of FSFI assessing sexual functioning in women. The result of PL-FSFI were compared with the control group.

Results. It was found that the mean score of PL-FSFI in the study group 3 months after the surgery was 13.33 points (score range: 1.2-31.7; median 8.3 points) with a statistically significant difference in terms of areas: desire, arousal, lubrication and orgasm in favour of the control group. The total score of PL-FSFI was significantly lower in women after mastectomy than in women after breast-conserving surgery. It has been shown that sexually active women in whom the surgery concerned the right breast (on the side of the dominant hand) scored lower on the scale "sexual functioning" of QLQ-BR-23 than women with surgery of the left breast, with this difference being statistically significant. There was a statistically significant correlation between the baseline performance status on the Zubrod scale and the scales: desire, lubrication and satisfaction of PL-FSFI. Living in a small town proved to be statistically significant for predicting a lower risk of sexual dysfunction among the surveyed women.

Conclusions. The women who underwent surgery due to breast cancer had a higher risk of sexual dysfunction compared to the general population. Higher risk of sexual dysfunction especially concerns women after mastectomy, those who underwent breast surgery on the side of the dominant hand, and those with a worse preoperative overall level of functioning of $\geq 1$ point on the Zubrod scale. A lower risk of disorders was observed in women living in smaller towns. The above factors indicate the advisability for sexology consultation in women with breast cancer.
\end{abstract}

\section{Key words}

mastectomy, sexual health, sexual dysfunction, desire, orgasm

\section{INTRODUCTION}

Normal sexual activity depends on a complex interrelationship among multiple systems, including physiological, biochemical, neurological and psychological. Furthermore, there are multiple factors associated with the diagnosis and treatment of cancer that have an impact on women's sexuality, including the complex psychologic and symptom burden of the disease and treatments, especially surgical treatment due to breast cancer.

Breast cancer is the most common malignancy among women in Poland. In recent years, according to the National Cancer Registry, the number of cases annually have exceeded 16,500 and increased in the last two decades by about 10,000. In Poland, breast cancer is now the most common (excluding lung cancer), cause of death by cancer among women (the number of deaths - about 5,500 a year) $[1,2]$. The disease itself as well as its mental and social aftermath can significantly

Address for correspondence: Joanna Streb Department of Oncology, The Jagiellonian University Medical College, ul. Śniadeckich 10, 31-531 Kraków, Poland e-mail: annaojs@interia.pl

Received: 02.08.2017; accepted: 04.04.2018; first published: 11.05 .2018 affect the quality of a woman's life [3]. Breast surgery can also affect the specific, not only in terms of aesthetics, but also the symbolic, area of a woman's identification. Especially as mastectomy involves stress and sometimes a feeling of shame and a loss of worth (i.e., the "half a woman" complex) [4]. In a study on the psychosocial consequences of mastectomy, analysis of social, professional and sexual health and the body image of women plays an important role $[5,6]$.

Because surgical treatment due to breast cancer has an impact on women's sexuality, there is therefore a need for research about effective indications for sexology consultation in women after surgical treatment due to breast cancer.

\section{OBJECTIVE}

The aim of this study is to determine the indications for sexology consultation in women after surgical treatment for breast cancer, considering the differences resulting from the specificity of surgery, as well as the medical and demographic characteristics of the surveyed women. 


\section{MATERIALS AND METHOD}

42 women who had undergone surgery from March December 2015 at the Department of Oncology of the the Jagiellonian University Medical College in Krakow met the inclusion criteria. The study included women aged 18-70, with early breast cancer, after surgery, who required adjuvant chemotherapy following the surgery, but without evidence of a generalised neoplastic process. Women in whom the clinical advancement corresponded to the IV degree, i.e., metastatic disease, were excluded from the observation. The youngest patient was 36 years old and the oldest was 68 , with a median of 56 years. The majority (59.5\%) of respondents were women from large cities (population $>300,000$ ) and women with a secondary education (35.7\%). $64 \%$ of the women reported a history of additional diseases (hypertension, ischemic heart disease, thyroid diseases, pulmonary diseases and diabetes). The patients' body mass index (BMI) was also calculated and was within the range: $16.5-38$ (median 26.7).

Depending on indications, the studied patients underwent one of 4 types of surgery. The most common (33.3\%) was breast-conserving therapy with sentinel lymph node biopsy $(\mathrm{BCT}+\mathrm{SNB})$. Other methods of surgery included: breastconserving therapy with auxiliary lymph node dissection $(\mathrm{BCT}+\mathrm{ALND})$ and mastectomy with sentinel lymph node biopsy, or with auxiliary lymph node dissection $(M+S N B$ or $\mathrm{M}+\mathrm{ALND}$ ). Depending on the technical possibilities and extent of the surgery, the women had one scar (removal of the tumour and lymphatic system in one operation) or 2 scars. All patients included in the study after surgery received adjuvant chemotherapy containing anthracyclines in a similar dose range and with a similar profile of side-effects.

Due to the fact that the presented study was observational in character and was conducted within a limited time and in a limited group of patients, a sample size selection formula was not applied, thus the observation group was not representative of the whole Polish population of the patients with breast cancer. This is an important limitation of the study. However, due to the diversity of the group in terms of features, such as age, place of residence, education, type of surgery, and breast size, it was decided to draw general conclusions.

The general characteristic of the group is presented in Table 1.

In order to determine the indications for sexology consultation in the group of women, depending on the method of breast cancer treatment, health covariates and quality of life, the following questionnaires were used:

1) Female Sexual Function Index in its Polish language version (PL-FSFI), used for the screening of sexual functioning of women $[7,8]$. The researchers obtained the written consent of the authors of the Polish version for the use of the questionnaire in the study. PL-FSFI includes 19 questions concerning the core emotional and physiological areas of sexual contact as occurring over the preceding 4 weeks. It takes into account 6 domains: desire, agitation, lubrication, experiencing orgasm, satisfaction with sexual and emotional relationship with a partner, and pain during vaginal intercourse. Point values, which make up the total score on a scale of $2.0-36.0$, are assigned to individual responses. A score of less than or equal to 27.5 points indicates a risk of sexual sphere disorders and is an indication for sexology consultation.

2) The standardised questionnaire EORTC QLQ-C30 (version 3.0) for the evaluation of the quality of life in cancer patients and its supplement designed for the study of women with breast cancer: Quality of Life Questionnaire for Breast Cancer (EORTC QLQ-BR23) [9, 10, 11]. The researchers obtained written consent for the use of EORTC questionnaires.

The patients completed the questionnaires in the $3^{\text {rd }}$ month following surgery. Each patient answered additional questions on demographic data: education, occupation, place of residence, breast size before the surgery (cup size A - E) and a subjective evaluation of the appearance of the scars after the surgery (possible variants of assessment: good, average, bad, I have no opinion). The PL-FSFI was also used to survey a randomly selected control group of 25 women aged 25-68 years with no prior history of cancer treatment. The presented results represent a fragment of a wider research project at the Department of Gynaecologic Oncology and Department of Oncology of the Jagiellonian University Medical College under the title: Subjective body image "Body self" and the level of sexual satisfaction in women undergoing gynaecological and oncological surgery. The study was approved by the Jagiellonian University Bioethics Committee (KBET/96/B/2013).

Statistical analysis was performed using Statistica 12.5. Analyses of independent variables were carried out using the Mann-Whitney U test and the multiple regression method.

\section{RESULTS}

19 of the 42 surveyed women (45\%) did not give a complete answer or refused to answer the PL-FSFI questionnaire. In $48 \%$ of the cases, the lack of response was associated with a lack of sexual contact for various reasons (lack of a partner $-16 \%$, "by choice" - $11 \%$, disease $-5 \%$, age $-5 \%$ ). $52 \%$ of the women did not give reasons for their refusal. The mean score of the PL-FSFI questionnaire in the study group 3 months

Table 1. The general characteristics of the study group

\begin{tabular}{|c|c|c|c|c|c|c|c|c|c|c|c|c|c|c|c|c|c|c|c|}
\hline \multirow[b]{2}{*}{ Statistics } & \multicolumn{3}{|c|}{ Place of residence } & \multicolumn{4}{|c|}{ Education } & \multirow{2}{*}{$\begin{array}{c}\text { Comorbid } \\
\text { internal } \\
\text { diseases }\end{array}$} & \multicolumn{4}{|c|}{ Type of the surgery } & \multicolumn{2}{|c|}{ Breast } & \multicolumn{5}{|c|}{ Breast size } \\
\hline & $\begin{array}{l}\text { Large } \\
\text { City }\end{array}$ & $\begin{array}{l}\text { Small } \\
\text { Town }\end{array}$ & Village & higher & $\begin{array}{l}\text { secon- } \\
\text { dary }\end{array}$ & $\begin{array}{l}\text { voca- } \\
\text { tional }\end{array}$ & primary & & $\begin{array}{c}\mathrm{BCT}+ \\
\mathrm{SNB}\end{array}$ & $\begin{array}{l}\text { BCT + } \\
\text { ALND }\end{array}$ & $\begin{array}{l}\mathrm{M}+ \\
\mathrm{SNB}\end{array}$ & $\begin{array}{c}\mathrm{M}+ \\
\text { ALND }\end{array}$ & right & left & $\begin{array}{c}\text { Cup } \\
\text { A }\end{array}$ & $\begin{array}{c}\text { Cup } \\
\text { B }\end{array}$ & $\begin{array}{c}\text { Cup } \\
\text { C }\end{array}$ & $\begin{array}{c}\text { Cup } \\
\text { D }\end{array}$ & $\begin{array}{c}\text { Cup } \\
\text { E }\end{array}$ \\
\hline$\%$ & 59.5 & 19.0 & 21.4 & 31.0 & 35.7 & 23.8 & 9.5 & 64.3 & 33.3 & 21.4 & 23.8 & 21.4 & 35.7 & 64.3 & 2.5 & 25.0 & 40.0 & 15.0 & 17.5 \\
\hline
\end{tabular}

$\mathrm{BCT}+\mathrm{SNB}$ - breast-conserving therapy with sentinel lymph node biopsy

$B C T+A L N D$ - breast-conserving therapy with axillary lymph node dissection

M+SNB - mastectomy with sentinel lymph node biopsy

M+ALAND - mastectomy with with axillary lymph node dissection 
after the surgery was 13.33 points (score range: $1.2-31.7$; median 8.3 points) and it was significantly lower than the result of the control group, which was 21.36 points. Comparison of the results of the individual scales of PL-FSFI with the control group revealed statistically significant differences in the areas of: desire, arousal, lubrication, and orgasm. In each of these areas women after breast surgery scored significantly lower than the control group. There were no significant difference in the scales "satisfaction with sexual intercourse" and "experiencing pain during vaginal intercourse" between the compared groups (Tab. 2).

Table 2. Comparison of PL-FSFI results between the group of women after surgical treatment for breast cancer and control group

\begin{tabular}{|c|c|c|c|c|c|c|c|c|}
\hline PL-FSFI & group & $n$ & mean & SD & median & $\min$ & $\max$ & $\begin{array}{c}\text { Mann- } \\
\text { Whitney } \\
\text { U Test }\end{array}$ \\
\hline \multirow{2}{*}{ total score } & study & 21 & 13.33 & 9.77 & 8.3 & 1.2 & 31.7 & \multirow{2}{*}{$\begin{array}{c}p= \\
0.0157\end{array}$} \\
\hline & control & 25 & 21.36 & 10.30 & 24.5 & 3.4 & 34.4 & \\
\hline \multirow{2}{*}{ Desire } & study & 21 & 2.01 & 0.83 & 1.8 & 1.2 & 3.6 & \multirow{2}{*}{$\begin{array}{c}p= \\
0.0089\end{array}$} \\
\hline & control & 25 & 2.93 & 1.28 & 3.0 & 1.2 & 6.0 & \\
\hline \multirow{2}{*}{ Arousal } & study & 21 & 1.51 & 1.45 & 1.2 & 0.0 & 4.5 & \multirow{2}{*}{$\begin{array}{c}p= \\
0.0154\end{array}$} \\
\hline & control & 25 & 2.92 & 1.90 & 3.0 & 0.0 & 5.7 & \\
\hline \multirow{2}{*}{ Lubrication } & study & 21 & 1.91 & 2.28 & 0.3 & 0.0 & 6.0 & \multirow{2}{*}{$\begin{array}{c}p= \\
0.0129\end{array}$} \\
\hline & control & 25 & 3.76 & 2.15 & 4.5 & 0.0 & 6.0 & \\
\hline \multirow{2}{*}{ Orgasm } & study & 21 & 1.94 & 2.08 & 1.2 & 0.0 & 6.0 & \multirow{2}{*}{$\begin{array}{c}p= \\
0.0247\end{array}$} \\
\hline & control & 25 & 3.49 & 2.07 & 4.0 & 0.0 & 6.0 & \\
\hline \multirow{2}{*}{ Satisfaction } & study & 19 & 3.11 & 1.72 & 3.0 & 0.0 & 6.0 & \multirow{2}{*}{$\begin{array}{c}p= \\
0.1906\end{array}$} \\
\hline & control & 25 & 3.84 & 1.96 & 4.4 & 0.4 & 6.0 & \\
\hline \multirow{2}{*}{ Pain } & study & 21 & 3.20 & 2.76 & 4.4 & 0.0 & 6.0 & \multirow{2}{*}{$\begin{array}{c}p= \\
0.1421\end{array}$} \\
\hline & control & 25 & 4.43 & 2.26 & 5.6 & 0.0 & 6.0 & \\
\hline
\end{tabular}

On comparing the results of the PL-FSFI obtained from women after mastectomy and women after breast-conserving treatment, it was noted that each time women who underwent mastectomy obtained a significantly lower overall score than women after breast-conserving treatment. Statistically significant differences were also evident in terms of the following parameters of sexual functioning: desire, arousal, lubrication. There was no difference between the groups of women after mastectomy and breast-conserving surgery in terms of orgasm, satisfaction with intimate relationships with a partner and pain experienced during intercourse. There was no relationship between the side of the surgery and the results of the PL-FSFI (Tab. 3).

In the QLQ-BR23, 2 items assess sexual functioning (14: "To what extent were you interested in sex?" and 15: "to what extent were you sexually active?") and one item assesses satisfaction with sexual intercourse (16: "To what extent was sex enjoyable for you?”). The overall result of QLQ-BR23 in the study group is presented in Table 4.

It has been shown that sexually active women, in whom treatment concerned the right breast (the side of the dominant hand) scored lower than women after surgery of the left breast on the scale "sexual functioning" of QLQ-BR23 (describing the degree of interest in sex and sexual activity in the previous 4 weeks), and this difference was statistically significant. However, there were no differences in the satisfaction with sexual intercourse (item 16 of QLQ-BR23), depending on the type of surgery (Tab. 5).
Table 3. Comparison of PL-FSFI results between distinguished groups of women after mastectomy (M), breast-conserving treatment (BCT) and control group

\begin{tabular}{|c|c|c|c|c|c|c|c|c|}
\hline PL-FSFI & surgery & $\mathrm{n}$ & mean & $\begin{array}{c}\text { st. } \\
\text { dev. }\end{array}$ & $\mathrm{Me}$ & $\min$ & $\max$ & $\begin{array}{c}\text { Kruskal- } \\
\text { Wallis rank } \\
\text { ANOVA }\end{array}$ \\
\hline & $\mathrm{BCT}$ & 13 & 14.00 & 9.54 & 8.3 & 4.0 & 27.6 & \\
\hline \multirow[t]{3}{*}{ Total score } & M & 8 & 12.25 & 10.71 & 10.2 & 1.2 & 31.7 & $p=0.0486$ \\
\hline & control & 25 & 21.36 & 10.30 & 24.5 & 3.4 & 34.4 & \\
\hline & $\mathrm{BCT}$ & 13 & 2.05 & 0.78 & 2.4 & 1.2 & 3.2 & \\
\hline \multirow[t]{3}{*}{ Desire } & M & 8 & 1.95 & 0.95 & 1.5 & 1.2 & 3.6 & $p=0.0308$ \\
\hline & control & 25 & 2.93 & 1.28 & 3.0 & 1.2 & 6.0 & \\
\hline & $\mathrm{BCT}$ & 13 & 1.57 & 1.41 & 1.5 & 0.0 & 3.9 & \\
\hline \multirow[t]{3}{*}{ Arousal } & M & 8 & 1.43 & 1.61 & 0.9 & 0.0 & 4.5 & $p=0.0498$ \\
\hline & control & 25 & 2.92 & 1.90 & 3.0 & 0.0 & 5.7 & \\
\hline & $\mathrm{BCT}$ & 13 & 2.03 & 2.38 & 0.3 & 0.0 & 6.0 & \\
\hline \multirow[t]{3}{*}{ Lubrication } & M & 8 & 1.73 & 2.24 & 0.9 & 0.0 & 6.0 & $p=0.0427$ \\
\hline & control & 25 & 3.76 & 2.15 & 4.5 & 0.0 & 6.0 & \\
\hline & $\mathrm{BCT}$ & 13 & 2.15 & 2.00 & 2.4 & 0.0 & 5.2 & \\
\hline \multirow[t]{3}{*}{ Orgasm } & M & 8 & 1.60 & 2.30 & 0.6 & 0.0 & 6.0 & $p=0.0769$ \\
\hline & control & 25 & 3.49 & 2.07 & 4.0 & 0.0 & 6.0 & \\
\hline & $\mathrm{BCT}$ & 13 & 3.06 & 1.78 & 3.0 & 0.0 & 5.6 & \\
\hline \multirow[t]{3}{*}{ Satisfaction } & M & 6 & 3.20 & 1.72 & 3.2 & 0.8 & 6.0 & $p=0.4068$ \\
\hline & control & 25 & 3.84 & 1.96 & 4.4 & 0.4 & 6.0 & \\
\hline & $\mathrm{BCT}$ & 13 & 3.23 & 2.87 & 4.4 & 0.0 & 6.0 & \\
\hline \multirow[t]{2}{*}{ Pain } & M & 8 & 3.15 & 2.77 & 3.8 & 0.0 & 6.0 & $p=0.3162$ \\
\hline & control & 25 & 4.43 & 2.26 & 5.6 & 0.0 & 6.0 & \\
\hline
\end{tabular}

Table 4. Results of QLQ-BR 23 in the group of women after surgical treatment for breast cancer

\begin{tabular}{lcccccc}
\hline BR-23 & $\mathrm{n}$ & Mean & st. dev. & Me & min & max \\
\hline body image & 42 & 64.71 & 31.55 & 67 & 0 & 100 \\
\hline sexual functioning & 35 & 12.80 & 17.09 & 0 & 0 & 50 \\
\hline $\begin{array}{l}\text { satisfaction wih sexual } \\
\text { intercourse* }\end{array}$ & 12 & 44.42 & 21.96 & 33 & 0 & 67 \\
\hline future prospect & 42 & 31.76 & 32.15 & 33 & 0 & 100 \\
\hline side-effects of systemic treatment & 42 & 41.93 & 18.20 & 43 & 5 & 78 \\
\hline breast symptoms & 42 & 20.93 & 21.68 & 17 & 0 & 78 \\
\hline arm symptoms & 42 & 21.98 & 22.99 & 17 & 0 & 100 \\
\hline hair loss** & $37^{* *}$ & 54.84 & 40.30 & 33 & 0 & 100 \\
\hline
\end{tabular}

* 21 cases not applicable

**3 cases not applicable

There were significant correlations between the performance status evaluated on the Zubrod scale before surgery and the PL-FSFI scales of: desire, lubrication and satisfaction, without affecting the scales measuring: arousal, orgasm and pain during intercourse. Statistically significant correlations between the general performance status determined before surgery on the Zubrod scale and the overall quality of life measured by QLQ-C30, as well as sexual functioning measured by QLQ-BR23 3 months after surgery, were also observed (Tab. 6).

This confirms the effectiveness of a simple general clinical scale for predicting the risk of decreased life quality and the occurrence of sexual functioning disorders in women after mastectomy. There was no correlation between the BMI and 
Table 5. Sexual functioning in women depending on side of the breast surgery

\begin{tabular}{|c|c|c|c|c|c|c|c|c|}
\hline $\begin{array}{l}\text { QLQ-BR23, } \\
\text { scales of } \\
\text { functioning }\end{array}$ & $\begin{array}{l}\text { Side of } \\
\text { surgery }\end{array}$ & $\mathrm{n}$ & mean & SD & $\mathrm{Me}$ & $\min$ & $\max$ & $\begin{array}{c}\text { Mann- } \\
\text { Whitney } \\
\text { U test }\end{array}$ \\
\hline \multirow{2}{*}{$\begin{array}{l}\text { Sexual } \\
\text { functioning }\end{array}$} & left & 22 & 17.36 & 18.07 & 17.00 & 0.00 & 50.00 & \multirow{2}{*}{$\begin{array}{c}p= \\
0.034\end{array}$} \\
\hline & right & 13 & 5.08 & 12.39 & 0.00 & 0.00 & 33.00 & \\
\hline \multirow{2}{*}{$\begin{array}{l}\text { Satisfaction } \\
\text { with sexual } \\
\text { intercourse }\end{array}$} & left & 9 & 44.33 & 17.00 & 33.00 & 33.00 & 67.00 & \multirow{2}{*}{ NS } \\
\hline & right & 3 & 44.67 & 38.68 & 67.00 & 0.00 & 67.00 & \\
\hline
\end{tabular}

* Higher values indicate a better functioning: min: 0, max: 100

Table 6. The higher the general level of impairment before surgery (Zubrod scale) - the lower the general quality of life and sexual functioning 3 months after the breast surgery

\begin{tabular}{|c|c|c|c|c|c|c|c|c|}
\hline Result/Scale & $\begin{array}{c}\text { Perfor- } \\
\text { mance } \\
\text { status } \\
\text { (PS 0-2) } \\
\text { Zubrod } \\
\text { Scale }\end{array}$ & $\mathrm{n}$ & mean & SD & Me & $\min$ & $\max$ & $\begin{array}{c}\text { Mann- } \\
\text { Whitney } \\
\text { U test }\end{array}$ \\
\hline \multirow{2}{*}{$\begin{array}{l}\text { General } \\
\text { quality of life / } \\
\text { QLQ-C30) }\end{array}$} & 0 & 21 & 67.06 & 18.16 & 66.67 & 33.33 & 100.00 & \multirow{2}{*}{$\begin{array}{c}p= \\
0.014\end{array}$} \\
\hline & 1 & 21 & 51.98 & 22.35 & 50.00 & 8.33 & 100.00 & \\
\hline \multirow{2}{*}{$\begin{array}{l}\text { Sexual } \\
\text { functioning / } \\
\text { QLQ-BR23 }\end{array}$} & 0 & 19 & 18.37 & 18.24 & 17.00 & 0.00 & 50.00 & \multirow{2}{*}{$\begin{array}{c}p= \\
0.030\end{array}$} \\
\hline & 1 & 16 & 6.19 & 13.30 & 0.00 & 0.00 & 33.00 & \\
\hline
\end{tabular}

the results of PL-FSFI, QLQ-C30 and QLQ-BR23 in terms of the effect on sexual functioning and sexual satisfaction in the surveyed women. There was also no correlation between the presence of other somatic diseases and the results of the PLFSFI or the results of QLQ-C30 and QLQ BR-23 in the study group. The patients' responses describing the dimension of "sexual enjoyment" in the QLQ-BR23 were compared with the total result of the PL-FSFI. Pearson's R correlation coefficient was used in this analysis. The obtained correlation was $\mathrm{R}=0.76$ at the significance level of $\mathrm{p}<0.001$, which proves the compliance of responses. In order to summarise the factors that may affect the final assessment of sexual satisfaction in the women surveyed, regression analysis, including the type of surgery (BCT vs. mastectomy), place of residence, education, and BMI (age-standardised), was performed. The model included education, place of residence and the assessment of scars following surgery. Other variables were not significant in the model. $\mathrm{R}$ for the entire model was $0.91, R^{2}-0.82$, the constructed model explains $82 \%$ of variation, the standard estimation error was 5.21, Fisher's statistic -5.23 , p for the model $-<0.0165$ (Tab. 7).

Only one component of the model - living in a small town $(<300,000)$ was statistically significant. On the basis of the model, one can say that comparing 2 women with the same education and the same age, equally satisfied with the healing of scars, place of residence - small town correlates with less risk of sexual dysfunction. The influence of individual variables on the results of FSFI was also examined, but none of them proved to be a statistically significant factor. The results of the FSFI for patients after mastectomy were compared separately depending on the perception of the scar after surgery and the size of the breast that had been removed. An ANOVA analysis was performed; also in this case it did not yield statistically significant results.
Table 7. Results of regression analysis of the influence of specified demographic variables on sexual satisfaction in woman with breast cancer

\begin{tabular}{lccc}
\hline Model components & $\begin{array}{c}\text { Regression } \\
\text { coefficient for } b\end{array}$ & $\begin{array}{c}\text { Standard error } \\
\text { for } b\end{array}$ & $p$ \\
\hline Living in a small town & 14.8 & 4.8 & 0.0148 \\
\hline Living in a village & -3.6 & 2.26 & 0.2803 \\
\hline Primary education & -3.87 & 4.3 & 0.3940 \\
\hline Vocational education & 10.0 & 5.8 & 0.1204 \\
\hline Higher Education & -7.7 & 3.9 & 0.0844 \\
\hline Assessment of scar & -2.5 & 1.8 & 0.2166 \\
\hline
\end{tabular}

\section{DISCUSSION}

Women treated for breast cancer experience a number of changes in the areas of psyche, intimacy, sexuality and relationships, which often involves a change in body image and a disorder in a woman's natural life cycle. Therefore, patients with breast cancer more often than healthy people may reveal abnormalities in many areas of life, including the area of sexual functioning [12-15]. The data suggest that $25 \%-90 \%$ of women following the surgical treatment of breast cancer display mental and sexual disorders. These may be somatic disorders, physiological problems, mental disorders (depression and anxiety), as well as problems in the relationship with a partner $[16,17]$.

Numerous studies indicate lower sexual activity in women with breast cancer compared to the general population [18, 19]. From the physiological perspective surgery within the breast, especially its surgical removal (mastectomy) can cause many anatomical and physiological disorders, which include: lymphedema of the limb, decreased muscle strength, limitation of shoulder mobility, faulty posture. All of these abnormalities can cause the sensation of pain, difficulty in lifting objects, which often leads to restrictions in daily activities [20,21]. According to data of the American Cancer Society, the main problems in the sexual sphere of women after mastectomy may be mainly related to more psychologically conditioned areas of experiencing arousal and orgasm, which is essential to the physiology of sexual intercourse [22].

The authors draw attention to the difficulties associated with an examination of the sexual sphere of women related to crossing the border of intimacy, pointing to the fact that most research is limited to asking general questions instead of performing detailed analysis of sexual activity (arousal, agitation, lubrication, masturbation, satisfaction) [16]. The fact that in the current study $45 \%$ of the surveyed women refused to answer the PL-FSFI questionnaire of sexual satisfaction, examining precisely these areas or gave incomplete answers, may confirm this observation and indirectly indicate difficulties in the area of sexual life. The results of the research conducted by Pytka and Spych [21] indicate that $78-88 \%$ of women experience decreased sexual satisfaction as a negative effect of cancer and therapy. Many authors point out that sexual dysfunction concerns mainly older women [23-26].

Cancer not only shapes the health of women, but also affects the lifestyle and changes their attitude towards their own bodies. The diagnosis and initiation of therapy brings many changes, both in the physical and mental sphere of a 
woman's life [21]. Graja et al. [27], in conducting research on the quality of life in women treated for breast cancer, have shown that a negative body image following surgery can trigger fears of relationship breakdown, especially due to an impairment in the partners' sexual relationship.

Arora et al. [25] in examining the quality of life after surgery and systemic treatment, noted that sexual functioning was significantly lower in patients undergoing systemic therapy, when compared to those patients treated only with surgery. This thesis is also consistent with the observations of other authors $[16,21]$. In the presented study, women undergoing surgery due to breast cancer, no matter whether it was mastectomy or breast-conserving therapy, scored significantly lower on the PL-FSFI scale when examining sexual functioning than was the case for women in the control group. The mean score of the PLFSFI (13.33 points) confirms the advisability for sexology consultation in the test group (such a recommendation refers to the score $\leq 27.5$ points). However, what is interesting in the randomly selected control group of healthy women, such a decision-making PL-SFSI cut-off point for consultation recommendation, as equally for the advisability of sexology consultation, does not distinguish the study population and the control group. This result is similar to the observations of other authors, in which using the FSFI revealed disorders in sexual functioning for as many as $67.4 \%$ of women prior to breast surgery when compared to $82.9 \%$ of women following the procedure. In this study, however, the cut-off point for consultation recommendation was lower -26.55 points [28].

Thus, the question arises as to whether such a high degree of revealed disorders in the FSFI is the result of excessive sensitivity to the tool, or perhaps we are witnessing a growing number of problems within the sexual sphere for the population as a whole? According to other researchers, the problems and physiological changes associated with the presence and treatment of breast cancer are usually related to sexual arousal, experiencing orgasm, desire and satisfaction with intimate relationships. These problems can be related with the side-effects of chemotherapy, hormonal therapy (the induction of premature menopause) and extent of the surgery [29].

Also, in our observation the most significant effect of cancer translated itself into a reduction in desire, arousal, problems with reaching the expected level of vaginal lubrication during intercourse and experiencing an orgasm. In each of these areas women following breast surgery reported greater interference than the control group, as well as women following mastectomy who revealed a greater severity of problems than women following breast-conserving surgery, which is broadly in line with the observations of the other authors cited above. The authors point out that the disturbances in the sexual sphere of women with breast cancer significantly correlate with the reduction of other indicators of quality of life [26]. The presented study also showed a statistically significant correlation between the overall quality of life measured by the QLQ-C30 and sexual functioning measured by QLQ-BR23 3 months after the surgery. In addition, a correlation between both of these indicators with the indicators of overall performance status was determined preoperatively using the Zubrod scale, which is consistent with the results of other authors confirming the correlation between sexual functioning in women following breast surgery and their general health [28].
This result also indicates the effectiveness of a simple clinical scale measuring the general performance for predicting the risk of decreased quality of life and the occurrence of sexual functioning disorders in women following mastectomy. The observations regarding the relationship of sexual dysfunction with age are a source of ambiguous data. Some authors have observed that older patients ( $>50$ years) reveal fewer disorders in the sexual sphere and a smaller reduction in the quality of life related to the change of body image and loss of a sense of being feminine over the course of breast cancer oncological treatment than younger women [30]. Others, however, have documented better indicators of sexual functioning in younger women [31]. The results obtained in the current study showed no correlation between sexual functioning disorders in the surveyed women and their age; they are also in accordance with a range of data available in the subject literature [32]. In the analysis of medical variables and sexual functioning in women with breast cancer it has been demonstrated with statistical significance that women following surgery within the right breast had worse indicators of sexual functioning than women following surgery within the left breast. This observation, given the context that all of the surveyed women were right-handed, may indicate that the malfunction of the dominant hand after the surgery translates itself not only into typically considered, e.g., for the purpose of rehabilitation, areas of patient functioning (work, self-service), but also into her intimate life. However, it is difficult to generalise this conclusion due to the study's lack of a comparative group of left-handed women. There is also no subject literature data confirming this observation. Other authors emphasise the importance of psychological support and sexology intervention in women treated for breast cancer [16].

Aanalysis of the premorbid level of patient functioning and the current impact of the disease and treatment on their relationship with a partner is especially important, while the identification and prevention of the symptoms of premature menopause, sexual function disorders and body image should be an area of particular interest to clinicians $[16,26,34,35]$. Interesting observations are related to earlier social functioning and premorbid sexual relationships in women with breast cancer. The authors draw attention to the aspect of the premorbid integration of women with her natural social environment [36], which shapes their subsequent ability to receive adequate support in the course of the disease and treatment $[16,33,34]$. In the context of these results, the presented observation that women living in smaller towns have fewer disturbances in sexual functioning and relationship with a partner than residents of large cities, may indicate the protective role of smaller, somewhat more inclusive communities for the better functioning of women equally in the area of sexual health. This findings might be interpreted according to microgenetic theory, which included the favorauble effects of environmental factors in symptom formation [37], that is in our research the sexual dysfunction after surgery due to brest cancer.

\section{CONCLUSIONS}

1) Women who underwent surgery due to breast cancer are characterised by an increased risk of sexual dysfunction, compared to the general population. 
2) The higher risk for sexual dysfunction can affect women following mastectomy, compared to women following breast-conserving surgery, women following breast surgery on the side of the dominant hand, and women qualified for treatment with a poorer overall functioning level, that is $\geq 1$ point on the Zubrod scale.

3) There is a lower risk of the onset of sexual dysfunction following breast surgery in women living in smaller towns, which can indicate the favourable effects of environmental factors in the proper adaptation to cancer.

4) The above combination of factors: the result of PL-FSFI $\leq 27.5$ points, mastectomy, surgery on the side of the dominant hand, the overall level of functioning, that is $\geq 1$ point on the Zubrod scale, and living in large cities, may argue for the necessity for sexology consultation in women with breast cancer.

\section{REFERENCES}

1. Jassem J, Krzakowski M. Zalecenia postępowania diagnostycznoterapeutycznego w nowotworach złośliwych. 2013; http://onkologia. zalecenia.med.pl

2. Tomalska J, Trytko A, Ogarek D i wsp. Ocena jakości życia kobiet po chirurgicznym leczeniu raka piersi zrzeszonych w klubach amazonek. Pielęgniarstwo XXI wieku. 2012; 4 (41): 85-89.

3. Chwałczyńska A i wsp. Jakość życia kobiet po mastektomii. Wiadomości Lekarskie. 2004; 57: 201-205.

4. Zegarski W. i wsp. Ocena jakości życia kobiet po mastektomii na podstawie standardowych kwestionariuszy: QLQ - C30 i QLQ - BR23. Nowotwory - Jurnal of Oncology. 2010; 6: 532-535.

5. Trzepiel K. Pacjenci po amputacjach. Magazyn Pielęgniarki i Położnej. 2007; 11: 26-27.

6. Życińska J. Znaczenie poczucia własnej skuteczności w kształtowaniu obrazu siebie i jakości związku małżeńskiego przez kobiety po mastektomii. Wydawnictwo Uniwersytetu Jagiellońskiego, Kraków 2006.

7. Rosen R, Brown C, Heiman J, et al. The Female Sexual Function Index (FSFI): a multidimensional self-report instrument for the assessment of female sexual function. J Sex Marital Ther. 2000; 26: 191-208.

8. Nowosielski K, Wróbel B, Sioma-Markowska U, Poręba R. Development and validation of the Polish version of the Female Sexual Function Index in the Polish population of females. J Sex Med. 2013; 10(2): 386-95.

9. http://groups.eortc.be/qol/questionnaires_downloads.htm

10. Rocławska AR. Ocena jakości życia kobiet po mastektomii. Psychoonkologia. 2015; 3: 116-124.

11. Sprangers M, Groenvold M, Arraras J, et al. The European Organization for Research and Treatment of Cancer breast cancer-specific qualityof-life questionnaire module: first results from a three-country field study. J Clin Oncol. 1996; 14: 2756-2768.

12. Schover LR. The impact of breast cancer on sexuality, body image, and intimate relationships. CA Cancer J Clin. 1991; 41:112-120

13. Gokgoz S, Sadikoglu G, Paksoy E. at al. Health Related Quality of Life among Breast Cancer Patients: a Study from Turkey. Global J Health Sci. 2011; 3(2).

14. Trzepiel K. Pacjenci po amputacjach. Mag Pielęgniarki i Położnej. 2007; 11: 26-27.
15. Zycińska J. Znaczenie poczucia własnej skuteczności w kształtowaniu obrazu siebie i jakości związku małżeńskiego przez kobiety po mastektomii. Kraków; Wydawnictwo Uniwersytetu Jagiellońskiego, 2006.

16. Schover LR. The impact of breast cancer on sexuality, body image, and intimate relationships. CA Cancer J Clin. 1991; 41: 112-120.

17. Dizon DS. Quality of life after breast cancer: survivorship and sexuality. The Breast J. 2000; 15(5): 500-504.

18. Barnaś E, Skręt A, Skręt-Magierło J, Sobolewski M. Jakość życia kobiet Z chorobą nowotworową piersi. Przegl Menopauz. 2009; 1: 15-19.

19. Kulesza-Brończyk B, Terlikowski R, Dobrzycka B. i wsp. Jakość życia kobiet po leczeniu operacyjnym raka sutka. Zdr Publ. 2009; 119(3): 293-297.

20. Jassem J, Krzakowski M. Rak piersi - Praktyczny Przewodnik dla Lekarzy. Gdańsk; Wydawnictwo VIA-MEDICA, 2009.

21. Pytka D, Spych M. Jakość życia pacjentek po zabiegu mastektomii. J Public Health Med Rescue 2012; 4: 42-49.

22. American Cancer Society. Sexuality for the Woman With Cancer http:// www.cancer.org/acs/groups/cid/documents/webcontent/002912-pdf. pdf

23. Kapała W. Chora po mastektomii. Mag Pielęg Poł. 2009; 3: 17-22.

24. Abasher SM. Sexual health issues in Sudanese women before and during hormonal treatment for brest cancer. Psychooncol. 2009; 18(8): 858-65.

25. Arora NK, Gustafson DH, Hawkins RP, et al. Impact of surgery and chemotherapy on the quality of life of younger women with brest canrcinoma; a prospective study. Cancer 2001; 92: 1288-98.

26. Montazeri A, Khdaninia M, Harirchi I, et al. Quality of life in patients with breast cancer before and after diagnosis: an eighteen months follow-up study. BMC Cancer 2008; 8: 330.

27. Graja T, Grodecka-Gazdowska S. Czynniki wpływające na jakość życia kobiet leczonych z powodu raka piersi. Przegl Ginekol Pol. 2005; 5: 115-120.

28. Čižauskaitė A, Ramanauskienė S, Mockienė V, Petrauskas D. Sexual functioning in women with breast cancer after mastectomy alone compared to mastectomy with flap surgery for breast reconstruction. Milan breast cancer conference. Webcast and residential. - 2015 June 23-26, European Institute of Oncology; p. 1-2, www.breastmilan.com

29. Emilee G, Ussher JM, Perz J. Sexuality after breast cancer: A review. Maturitas 2010; 66(4): 397-407.

30. King MT, Kenny P, Shiell A, Hall J, Boyages J. Quality of life three months and one year after first treatment for early stage breast cancer: Influence of treatment and patient characteristics. Quality Life Res. 2000; 9: 789-800.

31. Watters JM, Yau JC, O’Rourke K, Tomiak E, Gertler SZ. Functional status is well maintained in older women during adjuvant chemotherapy for breast cancer. Ann Oncology 2003; 14(12): 1744-1750

32. Wenzel LB, Fairclough DL, Brady MJ, et al. Age-related differences in the Quality of Life of breast carcinoma patients after Treatment. American Cancer Society 1999; 86(9): 1768-1774.

33. Manganiello A, Hoga LA, Reberte LM, et al. Sexuality and quality of life of breast cancer patients post mastectomy. Europ J Oncology Nursing 2011; 15(2): 167-172.

34. Mandelblatt J, Figueiredo M, Cullen J. Outcomes and quality of life following breast cancer treatment in older women: When, why, how much, and what do women want? Health Quality Life Outcomes 2003; 1(45): 1-11.

35. Cabak A. Expectations of the patients referred to physical and rehabilitation medicine doctors. Acta Neuropsychol. 2017; 17(1): 13-20.

36. Ziółkowski A, Błachnio A, Pąchalska M. An evaluation of life satisfaction and health - Quality of life of senior citizens. Ann Agric Environ Med. 2015; 22(1): 147-151. doi: 10.5604/12321966.1141385

37. Pąchalska M, Góral-Pólrola J, Mueller A, Kropotov JD. Neuropsychology and the neurophysiology of perceptual microgenesis. Acta Neuropsychologica 2017; 15(4): 365-389. doi: 10.5604/01.3001.0010.7243 